\title{
Lectotypification of some Freyn's names from the Iberian Peninsula
}

\author{
by \\ Karel Sutorý \\ Department of Botany, Moravian Museum, Hviezdoslavova 29a, 62700 Brno. ksutory@mzm.cz
}

\begin{abstract}
Sutorý, K. 2010. Lectotypification of some Freyn's names from the Iberian Peninsula. Anales Jard. Bot. Madrid 67(2): 97-102.

Lectotypes are designated for names published by Josef Freyn from the Iberian Peninsula in Bulletin de l'Herbier Boissier in 1893: Genista anglica var. pilosa, Leontodon reverchonii, Linaria supina var. glaberima, Scabiosa tomentosa var. cinerea, Trifolium hervieri, Valerianella willkommii and Vicia lusitanica. Relectotypification is done for Thymus portae. Names Arabis reverchonii Freyn and Astragalus aragonensis Freyn from the same publication are mentioned as well.
\end{abstract}

Keywords: Freyn, typification, Arabis, Astragalus, Genista, Leontodon, Linaria, Scabiosa, Thymus, Trifolium, Valerianella, Vicia.

\section{Introduction}

Descriptions of here lectotypified names were published in October 1893 in Bulletin de l'Herbier Boissier (Freyn, 1893). Most of them appear about three months later in Willkomm (1893) and sometimes was used this source as valid (Valdés, 1970; Galán Cela, 1990). Dates of publication of both are given according to Stafleu \& Cowan (1988).

Freyn used for his description in this article seven specimens send by E. Reverchon, two specimens of O. Buchtien and one specimen of P. Porta \& G. Rigo. The specimens were send to him probably with provisional half printed and half handwritten label (see Fig. 1 a, c, e) or only handwritten on paper (e.g. reverse side of another printed exsiccata label). Freyn added his determination and comments (printed in bold in the list below) and in a letter wrote his opinion back to the collector. Collectors added some details

\section{Resumen}

Sutorý, K. 2010. Lectotipificación de algunos nombres de Freyn publicados para la Península Ibérica. Anales Jard. Bot. Madrid 67(2): 97-102 (en inglés).

Se designan lectótipos para los nombres publicados por Josef Freyn para la Península Ibérica en la revista Bulletin de l'Herbier Boissier en 1893: Genista anglica var. pilosa, Leontodon reverchonii, Linaria supina var. glaberima, Scabiosa tomentosa var. cinerea, Trifolium hervieri, Valerianella willkommii y Vicia lusitanica. Se vuelve a lectotipificar Thymus portae. Se comentan además los nombres Arabis reverchonii Freyn y Astragalus aragonensis Freyn, publicados en la misma revista.

Palabras clave: Freyn, tipificación, Arabis, Astragalus, Genista, Leontodon, Linaria, Scabiosa, Thymus, Trifolium, Valerianella, Vicia.

about substrate, ecological character of the locality and elevation about the sea level, printed definitive labels that were distributed (also to Freyn, see Fig. 1 b, $\mathrm{d}, \mathrm{f}$ ). That is why there are in most cases two labels (provisional and definitive) in Freyn's collection. In the publication is this fact indicated as "in schedis". There is only one exception in Arabis reverchoni where is given in the publication "in litt." and the specimen is missing in Freyn's collection. The material was send probably back to the collector. Consequently we can say that material provided with "provisional" labels was studied by Freyn in the time of description. These specimens should be designated preferably as lectotypes. The material distributed later by Reverchon or by Porta and Rigo was not in his hands; it must be considered only as material from the same identical collection and could be used for this purpose only in the absence of original material, material with labels provided with Freyn's inscriptions. It 
corresponds to the second note of the ninth article of the ICBN (McNeill \& al., 2006): “... original material comprises ... those specimens ... upon which ... the description ... was based; ...; and (c) the isotypes or isosyntypes of the name irrespective of whether such specimens were seen by either the author of the validating description or diagnosis, or the author of the name...". Although the Recommendation 9A.4 of this Code "When a single gathering is cited in the protologue, but a particular institution bousing it is not designated, it should be assumed that the specimen housed in the institution where author is known to have worked is the holotype, unless there is evidence that further material of the same gathering was used" supports the necessity to choose the lectotypes from the material housed in the Moravian museum (BRNM). Freyn's collection was purchased for its herbarium collections in the year 1905 .

Three of discussed taxa (Scabiosa tomentosa var. cinerea, Trifolium hervieri, Valerianella willkommii) were distributed by E. Reverchon twice, not only in the year of collection (1882) but also in the next year 1883. We can't exclude it was collected only once in the first year. The collector is known to handle with his collections and labels not quite correctly in some cases (Burnat, 1883).

\section{Typification}

Arabis reverchonii Freyn, Bull. Herb. Boissier 1(10): 542.1893 ["Reverchoni"]

Ind. loc.: "Arragonia austr. In Sierra de Espadan prope Segorbiam Mayo 1892 leg. Reverchon”.

Current accepted name: Arabis nova Vill., Prosp. Hist. Pl. Dauphiné 39. 1779 (Greuter, Burdet \& Long, 1986; Talavera in Castroviejo \& al., 1993).

The specimen is missing in the BRNM herbarium. The name is not given even in the Freyn's original list of his specimens.

Astragalus arragonensis Freyn, Bull. Herb. Boissier 1(10): 544. 1893 [Astragalus aragonensis auct.]

Ind. loc.: "Arragoniae australi provincia Teruelensis. In montibus Sierra de Javalambra [sic] junio 1892 leg. Reverchon!”.

Current accepted name: Astragalus turolensis Pau, Not. Bot. Fl. Españ. 1: 20. 1887 (Podlech in Talavera $\&$ al., 1999).

In the description is given the name $A$. turolensis in synonymy, but with doubt ("An huc..."). According to the art. ICBN 52.1. and 52.2.e (McNeill \& al., 2006) the name is "illegitimate and is to be rejected if ... it definitely included the type... of a name or of which the epithet ought to have been adopted, under the rules ... by citation of the name itself or any name homotypic at that time ... which ought to bave been adopted". Podlech in Talavera \& al. (1999) considers this name as illegitimate, but it include $A$. turolensis with doubt, not "definitely". He added also the label "Holotypus" without further notes to the specimen at BRNM. According to Podlech 2009 isotypes should be preserved in FI and GOET.

BRNM 17746/34, lectotype selected by Podlech, designated here with three collector's labels, two of them provisional and one definitive:

- XX. Malacothrix il y, je crois, un Astragalus uralensis? stipulae [picture drawn by Freyn].

- Plantes d'Espagne 1892. Province de Teruel. E. Reverchon. A. aragonensis m. n. sp. JF No 39. Astragalus eriocarpus DC. Astrag. tab. 47 affinis! Sierra de Javalambra. Juin. rare.

- Elisée Reverchon -Plantes d'Espagne-1892, Province de Teruel No. 774 Astragalus aragonensis Freyn Sp. nov. Sierra de Camarena, á San Pueblo, pelouses rocheuses, sur le calcaiere, 1800 métres. Rare. Juin [Camarena de la Sierra lies in Sierra de Javalambre].

Genista anglica var. pilosa Freyn, Bull. Herb. Boissier 1(10): 543.1893

Ind. loc.: "Lusitania bor. prope Oporto leg. Buchtien!".

Current accepted name: Genista berberidea Lange, Descr. Icon. Pl. Nov. 1, tab. 1. 1864 (Talavera in Talavera \& al., 1999).

There are two labels with two numbers on the specimen.

BRNM 12131/34, with collector's original definitive label:

- Flora von Portugal, 95. Genista pilosa L. v. pilosa Freyn ad iter., Porto; Heiden bei Foz in das Vila des Meeres. 4. 1891. leg. Dr. O. Buchtien [Freyn's number] inv. 4609

BRNM 12132/34, lectotype designated hoc loco, with collectors handwritten label, some parts are written by Freyn:

- 95 Genista pilosa L. Wk. pd. III. 428! var. pilosa m. die jüngere Aeste sind behart während sie bei $G$. a. kahl sein sollen. Oporto. leg. Buchtien.

Leontodon reverchonii Freyn, Bull. Herb. 1(10): 547. 1893 ["Reverchoni"], nom. inval. [pro subsp. ("n. subsp.”)]; Freyn ex Willk., Suppl. Prodr. Fl. Hispan. 109. 1893 
Current accepted name: Leontodon pyrenaicus subsp. cantabricus (Widder) Finch \& P.D. Sell; Leontodon carpetanus auct. lusitan., non Lange Vid. Meddel. Dansk Naturh. Foren Kjobenhavn 1861: 96. 1861 (sec. Finch \& Sell, 1976).

The description is given for the subspecies and for both forms. The specimen in Freyn's collection are designated only with names of two forms, none is given as typical. In both descriptions (Freyn 1893a, 1893b) Freyn gives the name as subspecies "Leontodon Reverchoni Freyn n. subsp." and mentions the resemblance of $L$. pyrenaicus but on labels is it given in the specific rank "species nova".

\section{Leontodon reverchoni $f$. hispidus}

Ind. loc.: "Arragoniae australis provincia de Teruel in Sierra de Javalambra [sic] raro provenit. E. Reverchon!”.

BRNM 10111/36, lectotype designated hoc loco, with two collector's provisional labels:

- Plantes d'Espagne 1892 Province de Teruel E. Reverchon No 25 Leontodon Reverchoni m beta hispidus m. Sierra de Javalambre. Juin. rare.

- il y a un Leontodon Bourgeanum, je crois?

BRNM 10109/36, specimen with definitive printed label.

\section{Leontodon reverchoni f. subglaber}

Ind. loc.: "Arragoniae australis provincia Teruel: in locis humidis montium Sierra de Camarena. E. Reverchon! (sub L. carpetano)".

BRNM 10110/36, lectotype designated boc loco, specimen only with definitive printed label. Because there does not exist the material with provisional labels must it be selected as lectotypus.

Linaria supina var. glaberrima Freyn, Bull. Herb. Boissier 1(10): 547. 1893

Syn.: = Linaria badalii Willk. ex Loscos f. odoratissima (Bubani) Valdés (sec. Valdés, 1970).

Ind. loc.: "Arragonia austr. In Sierra de Camarena, junio leg. Reverchon!”.

Current accepted name: Linaria badalii var. glaberrima (Freyn) P. Galán Cela, Fontqueria 30: 114. 1990 [“(Freyn ex Willk.)”].

Even Galán Cela gives wrong place of description his combination is valid according to ICBN (McNeill \& al., 2006) Art. 33.7. The correct citation of the name is thus Linaria badalii var. glaberrima (Freyn) P. Galán Cela [not Linaria badalii var. glaberrima (Freyn ex Willk.) P. Galán Cela].
BRNM 01242/37, lectotype designated boc loco with collector's handwritten provisional label and with Freyn's inscriptions:

- Linaria supina Desf. Lge. in Prod. II. 571-2 var. glaberrima m. Sierra de Camarena Juin. rare 1892 Reverchon. Semina alata.

Scabiosa tomentosa var. cinerea Freyn, Bull. Herb. Boissier 1(10): 546. 1893

Ind. loc.: "Arragonia austr., in Sierra de Camarena, julio 1892 leg. Reverchon!”.

Current accepted name: Scabiosa turolensis Pau, Not. Bot. Fl. Españ. 1: 20.1887 (Devesa in Devesa \& al., 2007)

BRNM 13123/35, lectotype designated boc loco, collectors provisional label with Freyn's inscriptions (Fig. $1 \mathrm{a}, \mathrm{b}$ ):

- Plantes d'Espagne Province de Teruel, E. Reverchon No. 55, Scabiosa tomentosa var. cinerea m., Sierra de Camarena. Juillet.

BRNM 13124/35, with definitive collector's label:

- Elisée Reverchon -Plantes d'Espagne 1892, No. 762 Scabiosa tomentosa Cav. var. cinerea Freyn in litt. Sierra de Camarena, lieux arides, 1600 métres. Juillet.

Thymus portae Freyn, Bull. Herb. Boissier 1(10): 547. 1893

Ind. loc.: "Hispania, regnum Murcicum: Albasete in pascuis aridis ad radices montis Mugron prope Almasa 300-400 m. supra mare (Porta \& Rigo! No. 243)" [sic].

Current accepted name: Thymus antoninae Rouy \& Coincy Bull. Soc. bot. Fr. 165. 1890 (Huter, 1907; Greuter, Burdet \& Long, 1986).

BRNM 10468/37, lectotype designated hoc loco, definitive collectors printed label and two in pencil handwritten labels (Fig. 1 e, f):

- No. 443 Porta et Rigo. Iter III. Hispanicum 1891, Thymus portae Freyn. n. sp. 1891 (ex sect. Pseudothymbra) Albacete, in pascuis aridis mt. Mugran pr. Almasa, sol. calcar. 3-400 m s.m. 3 Junii.

- Diese Thymus wurden in grassigen? Stellen.gesammelt, scheinen aber bis auf 1-2 Formen sehr jung zu sein. Sollten sie etwa besser sehen währe ich recht dankbar im Interesse Port et Rigo, damit ich wenigstens einige Sorten oder Varietas aufführen konnte, da sonst einer schwere Menge im ... würde.

- 243 Thymus laxus n. sp.

Albacete in pascuis aridis ad radices mt. Mugron pr. Almasa 3-400 m s. 3. Juni Schaut doch etwas Besseres. Kelch u Blüthen lang!

The handwriting of the "note" (Porta or Rigo?) is 


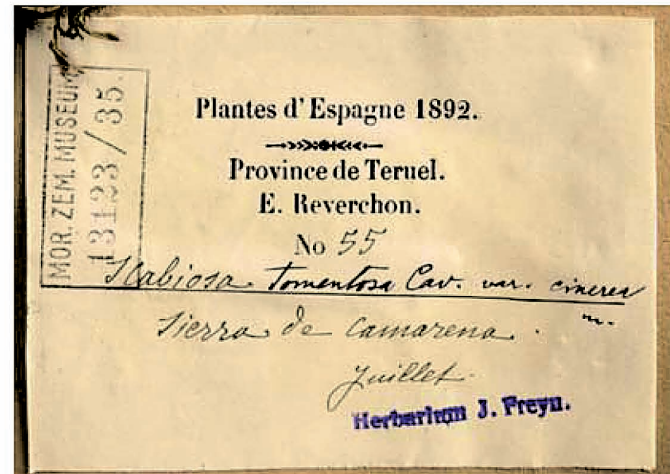

A

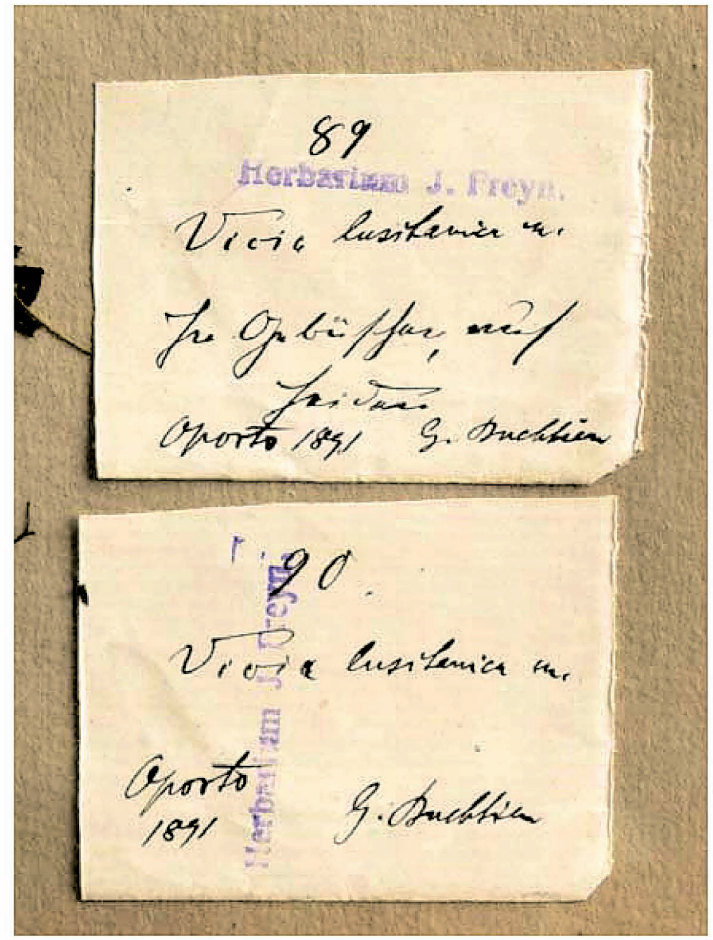

$\mathrm{C}$

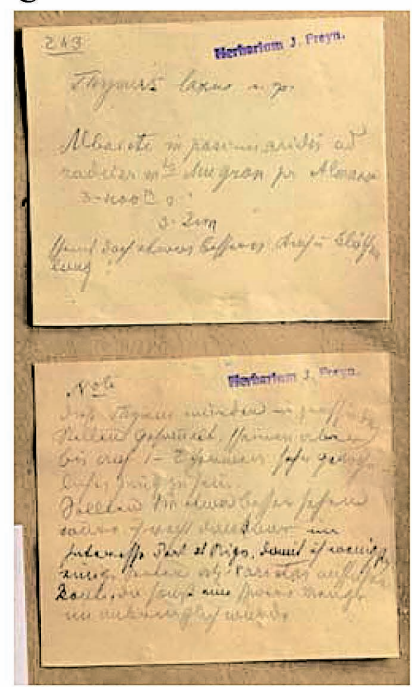

$\mathrm{E}$

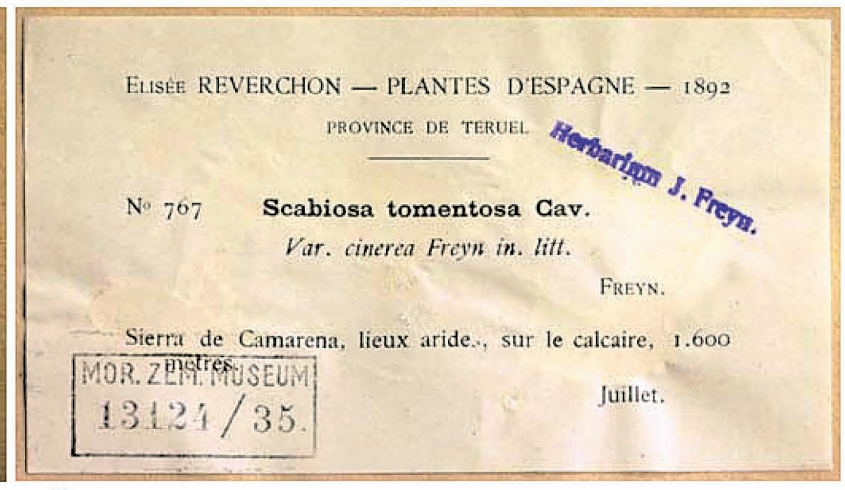

B

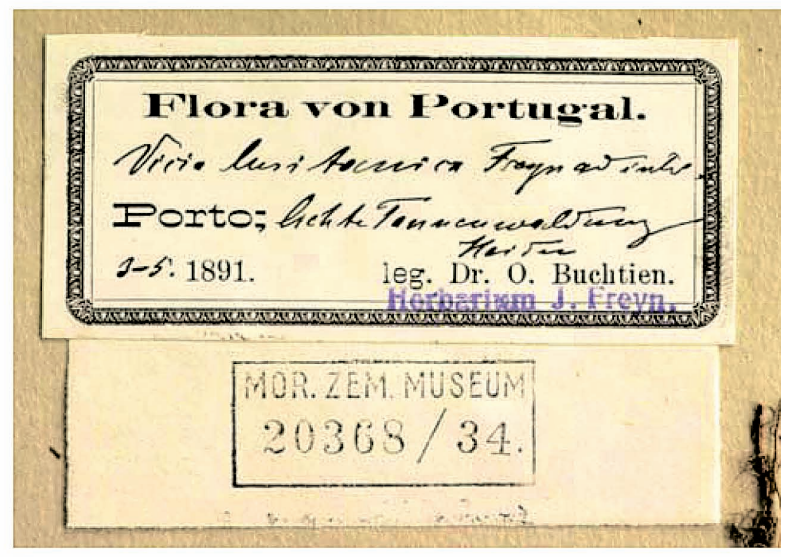

$\mathrm{D}$

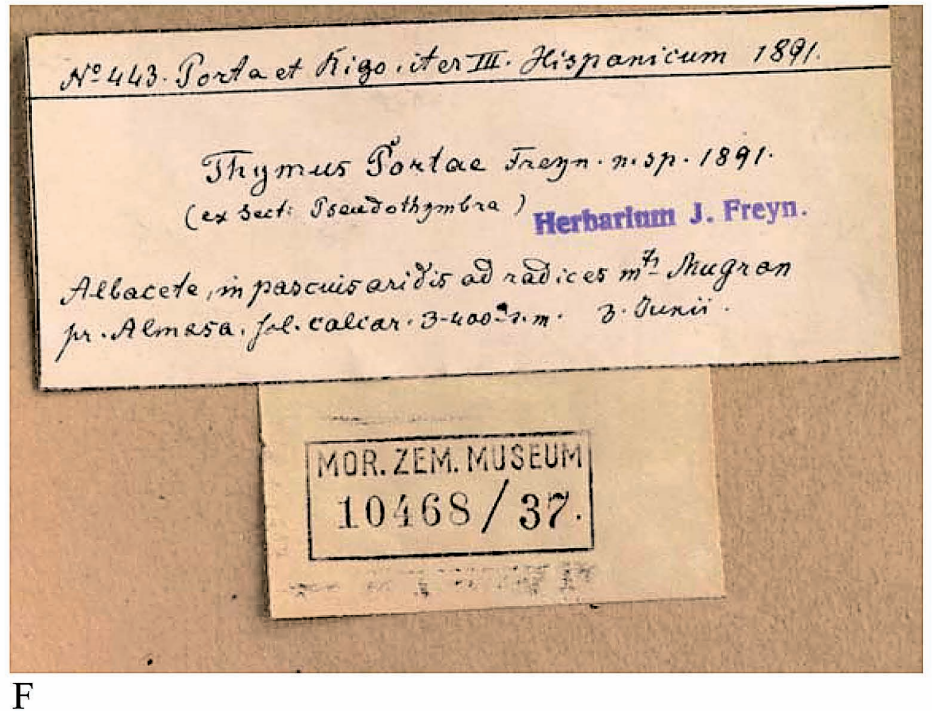

Fig. 1. A, provisional label of Scabiosa tomentosa var. cinerea; B, definitive label of Scabiosa tomentosa var. cinerea; C, provisional label of Vicia lusitanica; D, definitive label of Vicia lusitanica; E, provisional label of Thymus portae; F, definitive label of Thymus portae. 
identical with the later distributed multiplicated labels. The note probably accompanied more specimens and the specimen under discussion was from this material selected. The number " 243 " is given on the handwritten label and in the description erroneously. It should be "443". Morales Valverde (1986) typified Thymus portae Freyn with specimen MA 105678, because of reasons given in the introduction the lectotypification can't be accepted.

Trifolium hervieri Freyn, Bull. Herb. Boissier 1(10): 543.1893

Ind. loc.: "Arragonia austr. Provincia Teruel, in Sierra de Camarena 1892. leg. Reverchon!”.

Current accepted name: Trifolium sylvaticum Gérard ex Loisel. in J. Bot. (Desvaux) 2: 367.1809 (Muñoz Rodríguez, Devesa \& Talavera in Talavera \& al., 2000).

BRNM 16001/34, lectotype designated boc loco with two collector's original labels, provisional and definitive:

- Plantes d'Espagne 1892. Provincie Teruel, E. Reverchon No. 33 Trifolium herwieri m. Sierra de Camarena. Juin, rare.

- Elisée Reverchon -Plantes d'Espagne, No. 781 Trifolium Herwieri Freyn sp. nov. Sierra de Camarena, pelouses ombragées, su le calcaire, 1600 métres, rare. Juin.

There is another specimen collected on the same locality (later ?) and distributed by E. Reverchon in the year 1893 in the exsiccata series Plantae d'Espagne under the same number 781 (BRNM 16002/34).

Valerianella willkommii Freyn, Bull. Herb. Boissier 1(10): 546. 1893

Ind. loc.: "Arragoniae centr., inter segetes prope Camarena, junio (fructif.) leg. Reverchon!”.

Current accepted name: Valerianella martinii Loscos, Tratado Pl. Aragón 1: 23. 1876 (Devesa \& López Martínez in Devesa \& al., 2007).

BRNM 12514/35, lectotype designated boc loco with collector's handwritten label with Freyn's inscriptions and pictures of two details:

- Sect. Syncelae Pomel, Valerianella Willkommii m. n. sp. Camarena, les moissons. Juin. 1892 leg. Reverchon 14/1292.

There is another specimen in our collection (BRNM 12513/35) collected on this locality (later?) and distributed by E. Reverchon in the year 1893 in the exsiccata series Plantae d'Espagne under number 823 with the name $V$. willkommiana Freyn.
Vicia lusitanica Freyn, Bull. Herb. Boissier 1(10): 545. 1893

Ind. loc.: "Lusitania borealis. In fruticetis et ericetis ad Oporto vere 1891 leg. Buchtien”.

Current accepted name: Vicia angustifolia L., Amoen. Acad. 4: 105. 1759 (Romero Zarco in Talavera $\&$ al., 2000).

BRNM 20368/34, lectotype designated boc loco with one collector's label and two Freyn's in ink written labels (Fig. 1 c, d):

- Flora von Portugal Vicia lusitanica Freyn ad iter. Porto: Tannenwaldug Heiden 3-5 1891. leg. Dr. O. Buchtien.

- 89 Vicia lusitanica m. In Gebüschchen auf Heiden, Oporto $1891 \mathrm{lg}$. Buchtien.

- 90 Vicia lusitanica m. Oporto 1891 lg. Buchtien.

Plants on the sheet were collected according to the collectors label in March (plants only with flowers) and in Mai (plants also with developed legumes).

\section{Aknowledgements}

Thanks are due to Michal Hladík for taking the necessary photographs. The study was supported by the Czech grant agency grant no 206/071555 and the long term research grant MK 00009486201.

\section{References}

Burnat, E. 1883. Botanistes qui ont contribuué a flore des Alpesmaritimes, bibliographie et collections botaniques. Bulletin de la Société Botanique de France 30: CVII-CXXXIII.

Devesa, J.A. 2007. Scabiosa L. In: Devesa, J.A., Gonzalo, R. \& Herrero, A. (eds.), Flora iberica XV: 321-336. Real Jardín Botánico, CSIC, Madrid.

Devesa, J.A. \& López Martínez, J. 2007. Valerianella Mill. In: Devesa, J.A., Gonzalo, R. \& Herrero, A. (eds.), Flora iberica XV: 233-258. Real Jardín Botánico, CSIC, Madrid.

Finch, R.A. \& Sell, P.D. 1976. Leontodon L. In: Tutin, T.G., Heywood, V.H., Burges, N.A., Moore, D.M., Valentine, D.H., Walters, S.M. \& Webb, D.A. (eds.), Flora europaea 4: 310-315. Cambridge University Press, Cambridge.

Freyn, J. 1893. Neue Pflanzenarten der Pyrenäischen Halbinsel. Bulletin de l'Herbier Boissier 1(10): 542-548.

Galán Cela, P. 1990. Contribución al estudio florístico de las comarcas de la Lora y Páramo de Masa (Burgos). Fontqueria 30: 1-167.

Greuter, W., Burdet H.M. \& Long, G. 1986. Med-Checklist 3. Conservatoire et Jardin botaniques de la Ville de Genève, Genève.

Huter, R. 1907. Herbar-Studien. Oesterreichische Botanische Zeitschrift 57: 400-407.

McNeill, J., Barrie, F.R., Burdet, H.M., Demoulin, V., Hawksworth, D.L., Marhold, K., Nicolson, D.H., Prado, J., Silva P.C., Skog, J.E. \& Wiersema, J.H. (eds.) 2006. International Code of Botanical Nomenclature. (Vienna Code). Regnum vegetabile 146. A.R.G. Gantner Verlag KG, Ruggel.

Morales, R. 1986. Taxonomía de los géneros Thymus (excluida la sección Serpyllum) y Thymbra en la Península Ibérica. Ruizia 3: $1-324$. 
Muñoz Rodríguez, A., Devesa, J.A. \& Talavera, S. 2000. Trifolium L. In: Talavera, S., Aedo, C., Castroviejo, S., Herrero, A., Romero Zarco, C., Salgueiro, F. J. \& Velayos, M. (eds.), Flora iberica VII(2): 647-719. Real Jardín Botánico, CSIC, Madrid.

Podlech, D. 1999. Astragalus L. In: Talavera, S., Aedo, C., Castroviejo, S., Romero Zarco, C., Sáez, L., Salgueiro, F.J. \& Velayos, M. (eds.), Flora iberica VII(1): 279-338. Real Jardín Botánico, CSIC, Madrid.

Podlech, D. 2008. Thesaurus Astragalorum. München. http://www botanik.biologie.uni-muenchen.de/botsyst/thesau1.html

Romero Zarco, C. 2000. Vicia L. In: Talavera, S., Aedo, C., Castroviejo, S., Romero Zarco, C., Sáez, L., Salgueiro, F. J. \& Velayos, M. (eds.), Flora iberica VII(1): 360-417. Real Jardín Botánico, CSIC, Madrid.

Stafleu, F.A. \& Cowan, R.S. 1988. Taxonomic literature 7, ed. 2. Bohn, Scheltema \& Holkema, Utrecht/Antwerpen; dr. W. Junk, The Hague/ Boston.
Talavera, S. 1993. Arabis L. In: Castroviejo, S., Aedo, C., Gómez Campo, C., Laínz, M., Montserrat, P., Morales, R., Muñoz Garmendia, F., Nieteo Feliner, G., Rico, E., Talavera, S. \& Villar, L. (eds.), Flora iberica IV: 135-163. Real Jardín Botánico, CSIC, Madrid.

Talavera, S. 1999. Genista L. In: Talavera, S., Aedo, C., Castroviejo, S., Romero Zarco, C., Sáez, L., Salgueiro, F. J. \& Velayos, M. (eds.), Flora iberica VII(1): 45-119. Real Jardín Botánico, CSIC, Madrid.

Valdés, B. 1970. Revisión de las especies europeas de Linaria con semillas aladas. Anales de Universidad Hispalense, Ser. Cienc., $7.288 \mathrm{p}$.

Willkomm, H.M. 1893. Supplementum prodromi florae hispanicae. E. Schweizerbart, Stuttgartiae.

Associate Editor: G. López Received: 3-VI-2008 Accepted: 1-X-2010 